\title{
AN OBSERVATIONAL STUDY OF CLINICAL PROFILE AND MANAGEMENT OF NON-TRAUMATIC SMALL BOWEL PERFORATION AT TERTIARY CARE CENTRE
}

\author{
Kiran Somani1, Rishikant Vashistha², Sanjay Datey³, Abhishek Gurjar ${ }^{4}$, Akhilesh Patel ${ }^{5}$
}

1 Professor, Department of General Surgery, Sri Aurobindo Medical College and Postgraduate Institute, Indore, Madhya Pradesh, India. ${ }_{2}^{2}$ Associate Professor, Department of General Surgery, Sri Aurobindo Medical College and Postgraduate Institute, Indore,

Madhya Pradesh, India.

${ }^{3}$ Professor, Department of General Surgery, Sri Aurobindo Medical College and Postgraduate Institute, Indore, Madhya Pradesh, India. ${ }^{4}$ Senior Resident, Department of General Surgery, Sri Aurobindo Medical College and Postgraduate Institute, Indore, Madhya Pradesh, India.

5Senior Resident, Department of General Surgery, Sri Aurobindo Medical College and Postgraduate Institute, Indore, Madhya Pradesh, India.

\section{BACKGROUND}

ABSTRACT

Perforation peritonitis is a common surgical emergency faced by general surgeon in India. It is associated with significant morbidity and high mortality rate. This work has been carried out to study various aetiology, clinical feature, diagnostic dilemmas and management of non-traumatic small bowel perforation at a tertiary care centre. Traumatic small bowel perforations were not included in the study.

\section{MATERIALS AND METHODS}

This cross-sectional observational study was performed at a tertiary care centre. All patients undergoing exploratory laparotomy for non-traumatic small bowel perforation were included in the study from $1^{\text {st }}$ January 2015 to $30^{\text {th }}$ June 2016 . The patient's demographic data, clinical profile, diagnostic studies, intraoperative findings during laparotomy, surgical interventions performed, postoperative complications and final outcome were recorded and evaluated.

\section{RESULTS}

A total of 80 patients, 21 females and 59 males, between age ranges of 18 years and 90 years underwent exploratory laparotomy for non-traumatic small bowel perforation. Symptoms were abdominal pain, obstipation, abdominal distension, fever and vomiting. The cause of perforation was typhoid in 66 patients followed by ischaemic bowel disease in 6 and tuberculosis in 5 patients, and malignancy, intussusceptions, worm infestation in 1 patient each. 67 patients had ileal perforation, while 13 patients had jejunal perforation. 67 patients had single perforation, while 13 patients had multiple perforations. Various surgical procedures according to intraoperative findings were performed, $90 \%$ patients were discharged.

\section{CONCLUSION}

Typhoid fever is the most common cause of non-traumatic small bowel perforation followed by ischaemic bowel disease and tuberculosis in our study. Early surgical intervention under the cover of broad-spectrum antibiotics preceded by aggressive resuscitation and correction of electrolyte imbalance is imperative for good outcomes minimising morbidity and mortality.

\section{KEY WORDS}

Small Bowel Perforation, Typhoid, Exploratory Laparotomy.

HOW TO CITE THIS ARTICLE: Somani K, Vashistha R, Datey S, et al. An observational study of clinical profile and management of non-traumatic small bowel perforation at tertiary care centre. J. Evolution Med. Dent. Sci. 2018;7(32):3581-3584, DOI: $10.14260 /$ jemds/2018/804

\section{BACKGROUND}

Non-traumatic small bowel perforation is the most common form of gastrointestinal perforation in developing and underdeveloped nations. ${ }^{1}$ Perforation peritonitis is the most common emergency faced by general surgeon in India. ${ }^{2}$ Small bowel perforation is an acute surgical emergency, which may lead to multiorgan failure, sepsis and death if appropriate aggressive intervention is not done in a limited time.

'Financial or Other Competing Interest': None.

Submission 12-07-2018, Peer Review 28-07-2018,

Acceptance 30-07-2018, Published 06-08-2018.

Corresponding Author:

Dr. Rishikant Vashistha,

Associate Professor,

2-BB, Slice No. 5, Scheme No. 78,

Vijay Nagar, Indore, Madhya Pradesh, India.

E-mail: vashistha.rishikant@gmail.com

DOI: $10.14260 /$ jemds $/ 2018 / 804$
Perforation of small bowel leads to chemical and bacterial contamination, which may result in diffuse acute peritonitis. Patients with perforation are most of them usually presents with complaint of pain in abdomen, vomiting, fever and obstipation. In developing countries, perforation of small bowel due to typhoid and tuberculosis is common. ${ }^{3,4}$ Perforation of ileum due to typhoid is one of the commonest causes in developing countries, most probably due to low socio-economic condition, poor sanitation and poor personal hygiene. It is one of the most common causes of ileal perforation, which occur in 2nd and 3rd week of illness. The most lethal complications of typhoid fever are ileal perforation and intestinal bleeding both arising from necrosis of Peyer's patches in the terminal ileum. Typhoid ulcers can occur anywhere from stomach to rectum, but terminal ileum is more commonly involved due to higher density of Peyer's patches in the terminal ileum. ${ }^{5,6}$ 
Despite aggressive management and best of critical care facilities available, morbidity and mortality rates remain high. With the availability of new better antibiotics and advances in anaesthesia technique, laparotomy remains the first line of treatment for perforated bowel. The present mortality due to diffuse suppurative peritonitis ranges from $10 \%$ to $20 \%$, which continues to be unacceptably high. ${ }^{7}$ This study was done in our hospital to find out age and sex incidence, aetiological factors, clinical features and various surgical procedures for small bowel perforation and its complication and outcomes in our set-up.

\section{MATERIALS AND METHODS}

This cross-sectional observational study was conducted in the Department of General Surgery of Sri Aurobindo Medical College and Postgraduate Institute, Indore, over a period of 18 months between $1^{\text {st }}$ January 2015 and $30^{\text {th }}$ June 2016. The work was started after the review and approval of protocol of study by Institutional Ethics and Research Committees.

Study sample- 80 consecutive patients with diagnosis of non-traumatic small bowel perforation were included. Patients aged $>18$ years were included in the study. Proper consent from the patient was taken for his/ her inclusion in this study. A detailed clinical history was obtained for all the patients with the emphasis on the presenting complaints. A thorough physical examination was done for all patients. Vital signs were recorded. Information was documented for demographical data (age, gender), clinical features (Abdominal pain, distension of abdomen, vomiting, fever, cold peripheries, decreased urine output, constipation, dyspnoea, duration of symptoms, clinical examination findings (pulse, BP, temperature and abdominal examination to see for tenderness, localised guarding, rigidity). All patients underwent exploratory laparotomy after routine haematological and radiological investigations and record was made about the intraoperative findings and type of procedure done, any postoperative complications were noted and final outcome of the patients was evaluated.

\section{Statistical Analysis}

The mean and percentage value were calculated by using simple statistical methods. The final data was presented in the form of graphs and tables.

\section{RESULTS}

The table shows the distribution of patients according to age group. There were $3(3.8 \%)$ patients in the age group $<20$ years, $20(25 \%)$ were in the age group of $21-30$ years, 19 $(23.8 \%)$ were in the age group of $31-40$ years, $9(11.3 \%)$ were in the age group of 41 - 50 years and 17 (21.3\%) were in the age group of 51 - 60 years and 12 (15\%) were in the age group more than 60 years.

\begin{tabular}{|c|c|c|c|}
\hline Sr. No. & Age Group & Number & Percentage \\
\hline 1 & $<=20$ years & 3 & 3.8 \\
\hline 2 & $21-30$ years & 20 & 25.0 \\
\hline 3 & $31-40$ years & 19 & 23.8 \\
\hline 4 & $41-50$ years & 9 & 11.3 \\
\hline 5 & $51-60$ years & 17 & 21.3 \\
\hline 6 & $>60$ years & 12 & 15.0 \\
\hline \multicolumn{4}{|c|}{ Table 1. Distribution according to Age Group } \\
\hline
\end{tabular}

In the present study, $73.7 \%$ of the patients were males and $26.3 \%$ were females. The male-to-female ratio was 2.8: 1

\begin{tabular}{|c|c|c|c|}
\hline Sr. No. & Gender & Number & Percentage \\
\hline 1 & Female & 21 & 26.3 \\
\hline 2 & Male & 59 & 73.7 \\
\hline \multicolumn{4}{|c|}{ Table 2. Distribution according to Gender } \\
\hline
\end{tabular}

According to clinical presentation in 80 patients, abdominal pain in $80(100 \%)$ patients, abdominal distension in $57(71.3 \%)$ was present and obstipation in 70 (87.5\%) were the commonest presenting symptoms.

\begin{tabular}{|c|c|c|c|}
\hline Sr. No. & Clinical Presentation & Number & Percentage \\
\hline 1 & Abdominal pain & 80 & 100.0 \\
\hline 2 & Fever & 51 & 63.7 \\
\hline 3 & Abdominal distension & 57 & 71.3 \\
\hline 4 & Obstipation & 70 & 87.5 \\
\hline 5 & Vomiting & 44 & 55.0 \\
\hline \multicolumn{3}{|c|}{ Table 3. Distribution according to Clinical Presentation } \\
(Symptom) \\
\hline
\end{tabular}

Abdominal tenderness, guarding and rigidity with absent bowel sounds were the commonest presenting signs.

\begin{tabular}{|c|c|c|c|}
\hline Sr. No. & $\begin{array}{c}\text { Clinical } \\
\text { Presentation }\end{array}$ & Number & $\begin{array}{c}\text { Percentage } \\
\text { (\%) }\end{array}$ \\
\hline 1 & Tachycardia & 80 & 100 \\
\hline 2 & Tenderness & 28 & 35 \\
\hline 3 & Guarding/ Rigidity & 51 & 63.7 \\
\hline 4 & Absent bowel sound & 70 & 87.5 \\
\hline \multicolumn{3}{|c|}{$\begin{array}{c}\text { Table 4. Distribution according to Clinical Presentation } \\
\text { (Sign) }\end{array}$} \\
\hline
\end{tabular}

In our study typhoid in $66(82.5 \%)$, ischaemic bowel disease in $6(7.5 \%)$ and tuberculosis in $5(6.25 \%)$ patients are the most common causes of perforation.

\begin{tabular}{|c|c|c|c|}
\hline Sr. No. & Causes of Perforation & Number & Percentage \\
\hline 1 & Typhoid & 66 & 82.5 \\
\hline 2 & Tuberculosis & 5 & 6.25 \\
\hline 3 & Ischaemic bowel disease & 6 & 7.5 \\
\hline 4 & Malignancy & 1 & 1.25 \\
\hline 5 & Intussusception & 1 & 1.25 \\
\hline 6 & Worm infestation & 1 & 1.25 \\
\hline \multicolumn{3}{|c|}{ Table 5. Causes of Perforation } \\
\hline
\end{tabular}

In our study, ileal perforation $67(83.8 \%)$ are more common than jejunal perforation 13 (16.3\%).

\begin{tabular}{|c|c|c|c|}
\hline Sr. No. & Site & Number & Percentage (\%) \\
\hline 1 & Ileum & 67 & 83.8 \\
\hline 2 & Jejunum & 13 & 16.3 \\
\hline \multicolumn{3}{|c|}{ Table 6. Following Anatomical Site of Perforation } \\
\hline
\end{tabular}

There were single perforations, $67(83.8 \%)$ were more common than multiple perforations 13 (16.3\%).

\begin{tabular}{|c|c|c|c|}
\hline Sr. No. & Number of Perforations & Number & Percentage \\
\hline 1 & Single & 67 & 83.8 \\
\hline 2 & Multiple & 13 & 16.3 \\
\hline \multicolumn{3}{|c|}{ Table 7. Distribution according to Number of Perforations } \\
in each Patient \\
\hline
\end{tabular}




\section{Distribution of patients according to the Procedures Performed}

$51(63.75 \%)$ cases had undergone primary repair, followed by 11 (13.75\%) resections and primary anastomosis, $6(7.5 \%)$ resections and exteriorisation of bowel without anastomosis $(\mathrm{N}=80)$.

\begin{tabular}{|c|c|c|}
\hline Procedure & Number & Percentage \\
\hline Primary repair & 51 & $63.75 \%$ \\
\hline $\begin{array}{l}\text { Resection and primary } \\
\text { anastomosis }\end{array}$ & 11 & $13.75 \%$ \\
\hline $\begin{array}{l}\text { Resection and exteriorisation of } \\
\text { bowel }\end{array}$ & 6 & $7.5 \%$ \\
\hline $\begin{array}{l}\text { Resection and anastomosis with } \\
\text { stoma }\end{array}$ & 8 & $10.0 \%$ \\
\hline $\begin{array}{c}\text { Resection and exteriorisation of } \\
\text { bowel with pre-op stenting of } \\
\text { thrombosed artery }\end{array}$ & 2 & $2.5 \%$ \\
\hline Palliative drainage & 2 & $2.5 \%$ \\
\hline Total & 80 & 100.0 \\
\hline \multicolumn{3}{|c|}{$\begin{array}{c}\text { Table 8. Distribution according to Types of Surgical } \\
\text { Procedure Performed }\end{array}$} \\
\hline
\end{tabular}

In our study in 38 (47.5\%) surgical site infection was seen, in 13 (16.3\%) sepsis was seen and in 12(15\%) patient's chest infection were the most common complication $(\mathrm{N}=80)$.

\begin{tabular}{|c|c|c|}
\hline Complications & Number & Percentage \\
\hline Surgical site infection & 38 & 47.5 \\
\hline Wound dehiscence & 6 & 7.5 \\
\hline Sepsis & 13 & 16.3 \\
\hline Chest infection & 12 & 15 \\
\hline Faecal fistula & 3 & 7.5 \\
\hline Death & 8 & 10 \\
\hline Uneventful & 15 & 18.8 \\
\hline Table 9. Postoperative Complication and Course
\end{tabular}

There were $8(10 \%)$ deaths in our patients, while 72 $(90 \%)$ patients were discharged. Majority of the patients in our study were discharged $(\mathrm{N}=80)$.

\begin{tabular}{|c|c|c|}
\hline Outcome & Number & Percentage \\
\hline Death & 8 & 10.0 \\
\hline Discharged & 72 & 90.0 \\
\hline Total & $\mathbf{8 0}$ & $\mathbf{1 0 0 . 0}$ \\
\hline Table 10. Distribution of Patients according to Outcome \\
\hline
\end{tabular}

\section{DISCUSSION}

Infection is the commonest cause of such perforations in developing countries. Small bowel perforation is one of the commonest surgical emergencies. Present study was carried out on 80 patients. The age range observed in the study was from 20 years - 90 years. The mean age of the study population was $43.36 \pm 16.9$ years (Ratio of males-to-female participants was 2.8: 1). Most of the patients presented in the age group of 21 - 30 years. This might be due to the fact that typhoidal perforation are seen in young age group $20-30$ years. Similar observation was found in other studies of Rodolfo et al (2002), ${ }^{7}$ Dani et al (2015), ${ }^{8}$ Memon et al (2008). ${ }^{9}$

The most common complaint noticed in the study was abdominal pain followed by fever, abdominal distension, vomiting and constipation and the same being reported by Abdullah et al (2011).10 Ambikavathy et al (2013) ${ }^{11}$ and
Shaikh et al (2009).12 In our study, the main cause of perforation was due to typhoid. Other causes such as ischaemic bowel disease, tuberculosis, malignancy, intussusception and worm infestation were found in few cases. Typhoid fever was the predominant cause of nontraumatic small bowel perforation. It is the most common cause in developing countries due to lack of proper sanitation facilities. This was a similar finding in other studies where large bowel and malignant perforations were least common. ${ }^{11,13}$

Majority of the patients had purulent type of peritoneal fluid. This was the similar finding in other studies. ${ }^{8}$ But in contrary percentage of patients having faecal peritoneal fluid was significantly more, since in our study most common site of perforation was found to be in ileum which was attributed to typhoid infection. It is one of the most common infectious causes of small bowel perforation in developing countries like ours with poor basic sanitation and drinking water facilities. Majority of the patients had diffuse type of peritonitis. Our hospital being a tertiary centre most of the patients comes late, referred from periphery. Majority of the patients had single perforation, which was similar finding in comparison to other studies. ${ }^{10,11}$

\section{CONCLUSION}

There are innumerable causes, which may lead to small bowel perforation. Thus, there always persists a diagnostic dilemma in determining the aetiology leading to the small bowel perforation. Typhoid fever is the most common cause of ileal perforation followed by ischaemic bowel disease and tuberculosis.

Most of the patients presenting at tertiary centre are referred from peripheries with more diagnosis-surgery interval. Preoperative management of such cases are challenges and tests the skill techniques and knowledge of the surgeon.

No particular surgery is gold standard for the management of perforation peritonitis. Thus, every surgery is tailored in accordance with scenario on laparotomy, considering various parameters like age of patient, site, number and size of perforation, anaesthesia duration, type of peritoneal fluid, level of contamination, comfort of operating surgeon and protocol followed in particular institute.

\section{REFERENCES}

[1] Abantanga FA, Nimako B, Amoah M. Perforation of the Gut in children as a result of enteric fever: a 5 years single institute review. Annals of Pediatric Surgery 2009;5(1):1-10.

[2] Jhobta RS, Attri AK, Kaushik R, et al. Spectrum of perforation peritonitis in India-review of 504 consecutive cases. World Journal of Emergency Surgery 2006;1:26.

[3] Wani RA, Parray FQ, Bhat NA, et al. Nontraumatic terminal ileal perforation. World J Emerg Surg 2006;1:7.

[4] Atamanalp SS, Aydinli B, Ozturk G, et al. Typhoid intestinal perforations: twenty-six year experience. World J Surg 2007;31(9):1883-8.

[5] Beniwal US, Jindal D, Sharma J, et al. Comparative study of operative procedures in typhoid perforation. Indian J Surg 2003;65:172-7. 
[6] Na'aya HU, Eni UE, Chama CM. Typhoid perforation in Maiduguri, Nigeria. Ann Afr Med 2004;3(2):69-72.

[7] Bracho-Riquelme RL, Melero-Vela A, Torres-Ramirez A. Mannheim Peritonitis Index validation study at the hospital general de Durango (Mexico). Cir Ciruj 2002;70:217-25.

[8] Dani T, Ramchandra L, Nair R, et al. Evaluation of prognosis in patients' with perforation peritonitis using Mannheim's peritonitis index. International Journal of Scientific and Research Publications 2015;5(5)1-35.

[9] Memon AA, Bhutto AA, Shaikh SG, et al. Spectrum of diseases in patients with non-traumatic acute abdomen. J Liaquat Univ Med Health Sci 2008;7:1803.
[10] Abdullah MS, Rassam RE, Almarzooq TJ. A study of 82 patients of non-traumatic terminal ileal perforation in Al-Kindy teaching hospital. J Fac Med Baghdad 2011;2:147-51.

[11] Ambikavathy M, Bhaskaran A, Kumar S, et al. Nontraumatic ileal perforation: Surgical experience in rural population in Indian scenario. IJBAR 2013;04(01):47-55.

[12] Shaikh GS, Soomro Q, Bhutto AA, et al. Typhoid ileal perforation experience of 62 cases at Chandka Medical College Hospital, Larkana. J Med Channel 2009;15:187-90.

[13] Malhotra MK, Singal R, Chowdhary K, et al. Spectrum of perforation peritonitis in a rural medical college. Bangladesh Journal of Medical Science 2016;15(1):703. 